Annals of Warsaw University of Life Sciences - SGGW

Land Reclamation No 41, 2009: 71-82

(Ann. Warsaw Univ. of Life Sci. - SGGW, Land Reclam. 41, 2009)

\title{
The Shuttle Radar Topography Mission Digital Elevation Model as an alternative data source for deriving hydrological characteristics in lowland catchment - Rogożynek catchment case study
}

\author{
MICHAŁ WASILEWSKI, JAROSŁAW CHORMAŃSKI \\ Department of Hydraulic Engineering and Environmental Recultivation, Warsaw University of Life \\ Sciences - SGGW
}

\begin{abstract}
The Shuttle Radar Topography Mission Digital Elevation Model as an alternative data source for deriving hydrological characteristics in lowland catchment - Rogożynek catchment case study. This paper describes possibility of supplementing digital topography data needed for hydrologic modeling (WetSpa model) of lowland catchment with existing, freely available DEM data obtained from Shuttle Radar Topography Mission launched on February 11th, 2000. Rogożynek basin (Upper Biebrza) as case study is given. Authors compared three DEMs: topographic - TOPO DEM 20 (20 m resolution), radar - SRTM DEM 90 (90 m res.) and resampled radar - SRTM DEM 20 (20 m res.). There were several characteristics compared and analyzed like: relative height differences, slopes, generated river network and generated subwatersheds (subbasins).
\end{abstract}

Key words: Shuttle Radar Topography Mission, Digital Elevation Model, WetSpa model, hydrological characteristics derivation, watershed delineation, generating stream network from DEM.

\section{INTRODUCTION}

The good quality spatial data is a requirement for distributed hydrological modeling. Most of existing distributed models use numeric data as a GIS-grid dataset. One of the most important spatial input becomes terrain elevation and relief information, which is usually stored in form of Digital Elevation Model (DEM). It is used for determination of potential flow paths, and drainage areas especially important for rainfall-runoff models. This paper discusses SRTM3 DEM (Shuttle Radar Topography Mission-3 Digital Elevation Model) as a potential data source for hydrologic modeling in lowland catchments. Due to lack of topographic data for part of the basin selected for this study, decision was made to extend the available DEM using data from public domain dataset which is SRTM-3 DEM. This paper presents results of SRTM-3 DEM quality assessment analysis before it would be used as an extension of DEM from topographic sources (1:25000 topographic maps).

\section{MATERIALS AND METHODS}

\section{Research area}

The Biebrza catchment is located in north-eastern Poland. The research area contains upper part of the Biebrza catchment up to Rogożynek profile, with 2 tributaries: Niedźwiedzica River and Nurka River. Biebrza flows trough a flat, old ice-marginal valley, which is crossed 
by numerous ditches of reclamation system build in 70's of 20th century. The organic soils are dominant in valley part, while the moraine plateau is built of mineral soils. The catchment area is ca 14700 ha, from which $20 \%$ is located outside of Polish border on Belarusian territory, and not covered by available topographic maps (Fig. 1, Tab. 1). A Polish part of catchment is mainly used by agriculture with the only $16 \%$ of the area forested.

\section{WetSpa and WetSpa Extension}

WetSpa (Water and energy transfer between Soil, plants and atmosphere) is a GIS grid-based distributed hydrological model for flood prediction on hourly time step. WetSpa was originally developed by Wang et al. (1996) and adopted for flood prediction on hourly time step by De Smedt et al. (2000), and Liu et al. (2002). Model was applied in numerous settings which are mountain and lowland catchments (Liu 2004) as well as wetland areas (Chormański et al. 2007). The main outputs of the model are discharge hydrographs, and spatially distributed hydrological characteristics, such as soil moisture, infiltration rates, groundwater recharge, surface water retention or runoff, etc. The model can be defined for numerous subcatchments and verified on any location in the channel network, and can simulate the spatial distribution of catchment hydrological characteristics. The input to the model is hydro-meteorological data: precipitation, temperature, potential evapotranspiration, and discharge used

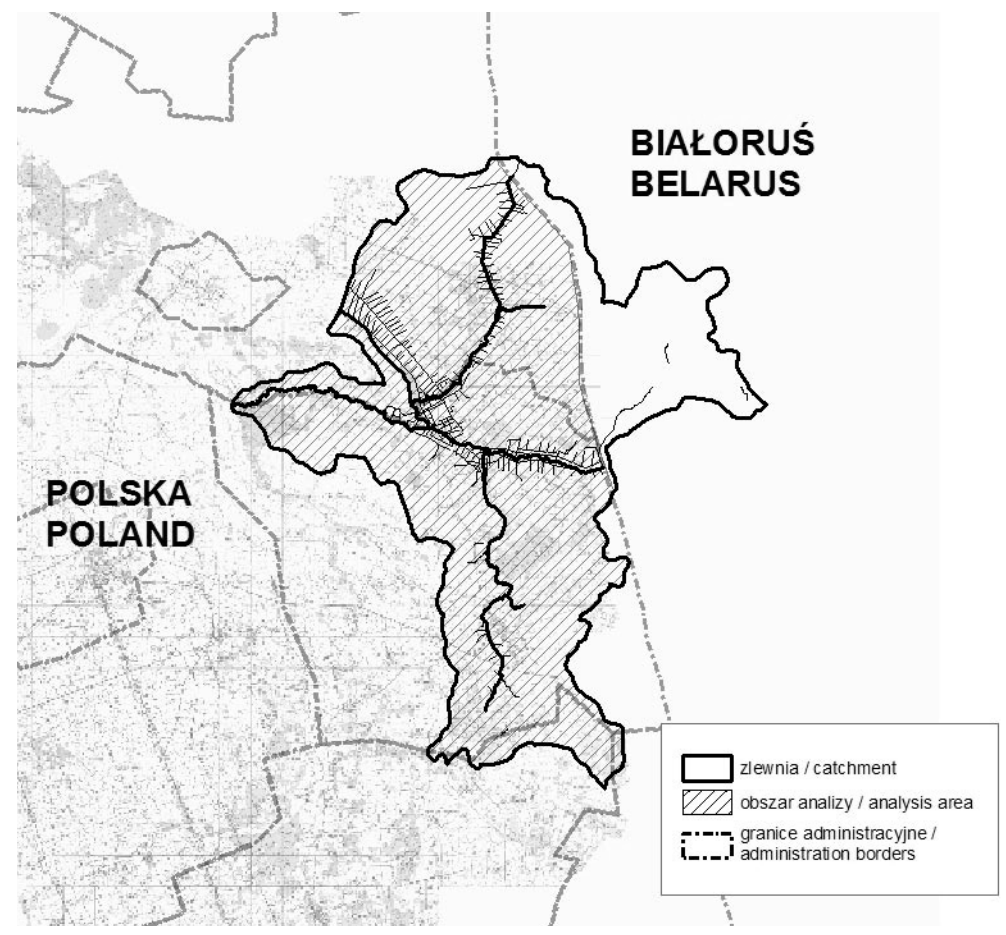

FIGURE 1. Location of investigated catchment (bold line - catchment boundary) 
TABLE 1. Analysis of stream networks concurrence - percentage of total analyzed area (11 $760 \mathrm{ha})$

\begin{tabular}{|l|c|c|c|c|}
\hline Dataset & Cells total & Cell resolution [m] & Network area [ha] & $\begin{array}{c}\text { Percentage of } \\
\text { catchment area [\%] }\end{array}$ \\
\hline TOPO 20 & 1364 & 20 & 54,56 & 0,46 \\
\hline SRTM 90 & 368 & 90 & 298,08 & 2,53 \\
\hline SRTM 20 & 1219 & 20 & 48,76 & 0,41 \\
\hline
\end{tabular}

for model calibration. Model parameters such as interception storage capacity, depression storage capacity, potential runoff coefficient, overland roughness coefficient, root depth, soil property parameters, average travel time to the outlet, dispersion coefficient and so on, are firstly calculated for each grid cell using ArcView lookup tables and the high resolution DEM (Digital Elevation Model), soil type and land use maps, or a combination of the three base maps. The model is implemented in GIS as an extension to ArcView 3.2 - WetSpa Extension. Runoff from different cells in the watershed is routed to the watershed outlet depending on flow velocity and wave damping coefficient by using the diffusive wave approximation method (De Smedt et al. 2000) in the form of an instantaneous unit hydrograph (IUH). Runoff is calculated as spatially distributed, and can be obtained by integration along the topography determined directly from DEM flow paths as a function of flow celerity and dispersion coefficient. The quality and accuracy of the digital representation of topography in form of DEM is an important factor, which influences modeling results. Therefore to ensure appropriate accuracy of DEM (partly missing in part of basin) authors decided to use SRTM mission datasets as supplementary data.

\section{SRTM}

The Shuttle Radar Topography Mission (SRTM) was a mission of the Endeavour space shuttle started on 11 February 2000. The objective of this project was to produce most accurate digital topographic data in global scope based on radar interferometry. The data was collected for $80 \%$ of the Earth's land surface (all land areas between $60^{\circ}$ north and $56^{\circ}$ south latitude). The spatial resolution of SRTM data is $30 \mathrm{~m}$ for USA territory and $90 \mathrm{~m}$ for rest of the World. SRTM DEM 90 (resolution of 90 $\mathrm{m}$ ) is determined upon interferometrical measurements in microwave band C. Accuracy of the SRTM DEM 90 is validated as better than analogical DEM interpolated from topographic maps in scale of 1:50 000 (Jarvis et al. 2004). The vertical absolute error for Poland is assumed as being in range of 4-5 m (Rodriguez et al. 2005).

\section{DEM processing}

The quality assessment of the SRTM DEM of the Polish part of the upper Biebrza catchment was conducted in several steps. The first step was an establishment of the elevation truth as an errorless DEM (errorlessness is assumed in sake of further comparisons in this paper). The errorless DEM was determined based on contour lines from 
topographic maps in scale of 1:25000 and topography measurements in the area of the flat valley. It was interpolated using TOPO to Raster algorithm (Hutchinson 1996) in ArcGIS 9 with resolution of 20 $\mathrm{m}$, and in this paper it would be called TOPO DEM 20. The quality assessment of the SRTM DEM was next performed by comparison with TOPO DEM 20. TOPO DEM was compared with original resolution SRTM DEM $90(90 \mathrm{~m})$ and resampled to $20 \mathrm{~m}$ resolution (SRTM DEM 20). Because the SRTM DEM is distributed in universal coordinate system WGS-84 it was transformed to Polish local coordinate system PUWG 65 , same as topographic source maps, prior to analysis. During comparison selected terrain patterns were analyzed: relative elevation differences, local slopes, hydrographic network and sub-catchments. The comparison was performed on regular grid consisting of 400 points extracted from both SRTM DEMs and TOPO DEM 20. Additionally, the relative elevation differences were calculated as a map of differences computed by subtracting the SRTM DEM from the TOPO DEM 20. All analyses and transformations were performed in ArcGIS 9.x.

\section{Hydrological patterns derivation}

Flow across a surface will always be in the steepest downslope direction. Once the direction of flow out of each cell is known, it is possible to determine which and how many cells contribute to any given cell. This information can be used to define watershed boundaries and stream networks.

The hydrographic patterns delineating subwatersheds and defining stream networks - are generated with use of functions from ArcGIS Hydrologic Toolset, also known as ArcHydro extension (Fig. 2). During patterns derivation authors proceeded through a series of steps according to Tarboton (Tarboton et al. 1991). First, the DEM is used to determine which cells flow into which cells - the flow direction. However, if there are errors in the elevation model, there are some cell locations that are lower than all the surrounding cells. If this is the case, all water traveling into the cell will not travel out. These depressions are called sinks. Using the hydrologic analysis functions of ArcGIS the sinks were identified (SINK) and filled (FILL), and the result was stored as a depressionless elevation model. Next, the flow direction (FLOW DIRECTION) of this depressionless elevation model was determined, and the flow accumulation (FLOW ACCUMULATION) for each cell location was calculated. Based on that, the digital stream network was determined (STREAM NETWORK) by adjusting of contribution cells threshold value. This gives a stream network comparable to existing one. During delineation of watersheds (WATERSHED), the pour points (locations that we wish to know the contributing watershed for) were specified as mouths of streams determined in previous step. This resulted in creating watersheds for each stream segment between stream junctions.

Additionally the procedure explained above was improved by including of the DEM Reconditioning function after FILL function. This function modifies DEM by imposing linear vector coverage onto raster (burning/fencing) based on 


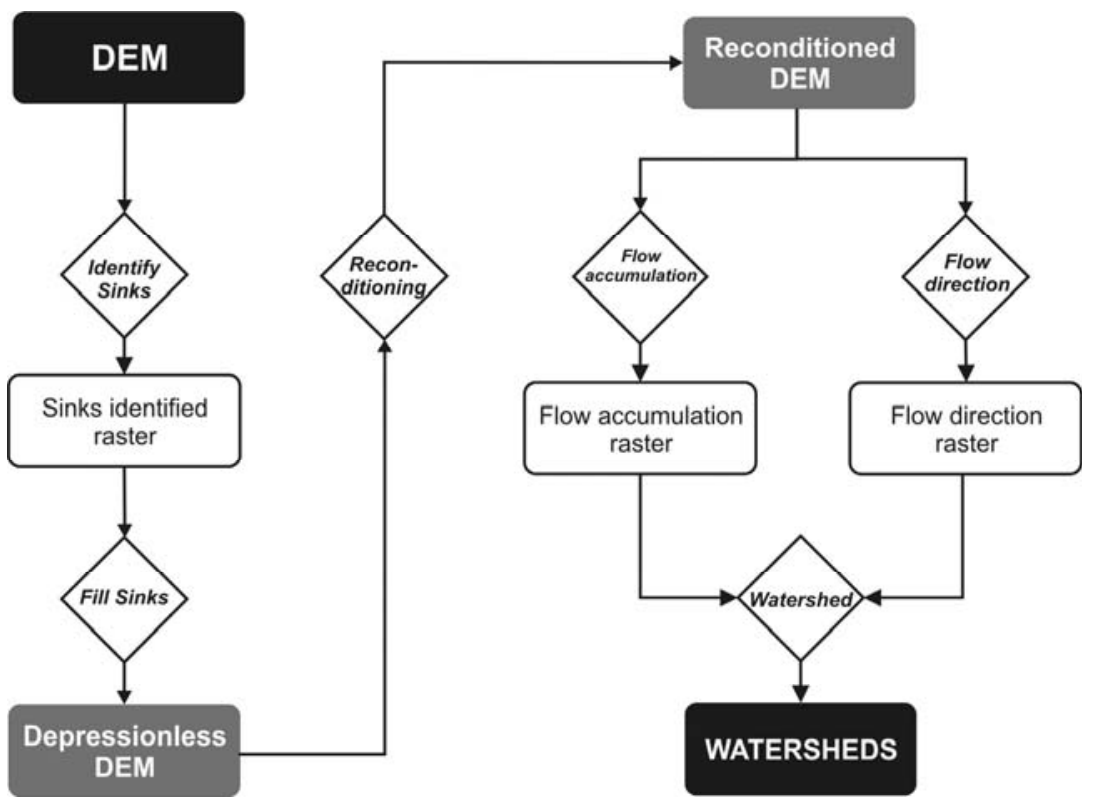

FIGURE 2. Algorithm to produce hydrological information from DEM using geoprocessing functions built into GIS systems

AGREE method developed by Hellweger (1997). The results were referred to as "Enhancing" and were compared to previously explained procedure. Figure 2 shows the algorithm of extracting hydrologic information from DEM.

\section{RESULTS AND DISCUSSION}

\section{Heights}

SRTM DEM 90 having smaller resolution than TOPO DEM 20 shows lesser terrain variability and greater generalization of ground features. SRTM DEM 90 has also greater maximum height values than TOPO DEM 20; maximum: 207 $\mathrm{m}$ a.s.l. - SRTM DEM 90; $198 \mathrm{~m}$ a.s.l. - TOPO DEM 20, while minimal values are comparable: 116 and $115 \mathrm{~m}$ a.s.l. respectively.
Relative elevation differences map and calculations carried out on a sample of 400 points show nearly $90 \%$ of values enclosed in $\mathrm{a}-5$ to $5 \mathrm{~m}$ range, where mean value is $0.57 \mathrm{~m}$ for SRTM90/TOPO20 comparison and $0.64 \mathrm{~m}$ for SRTM20/ /TOPO20 comparison which is lesser than results obtained by Karwel and Ewiak (2006) for corresponding region by $2.13 \mathrm{~m}$ and $2.06 \mathrm{~m}$ respectively. Variation range of $90 \%$ absolute error values is in range given for Poland (Rodriguez et al. 2005). Bigger discrepancies between analyzed areas were observed at valley edges and forested areas. Such areas, however, make a small amount of the whole catchment.

Standard deviation for SRTM90/ /TOPO20 comparison data set illustrated in Figure 3 is $\sigma=4.2 \mathrm{~m}$ where SD for SRTM20/TOPO20 comparison dataset presented in Figure 4 is $\sigma=3.89 \mathrm{~m}$. This 


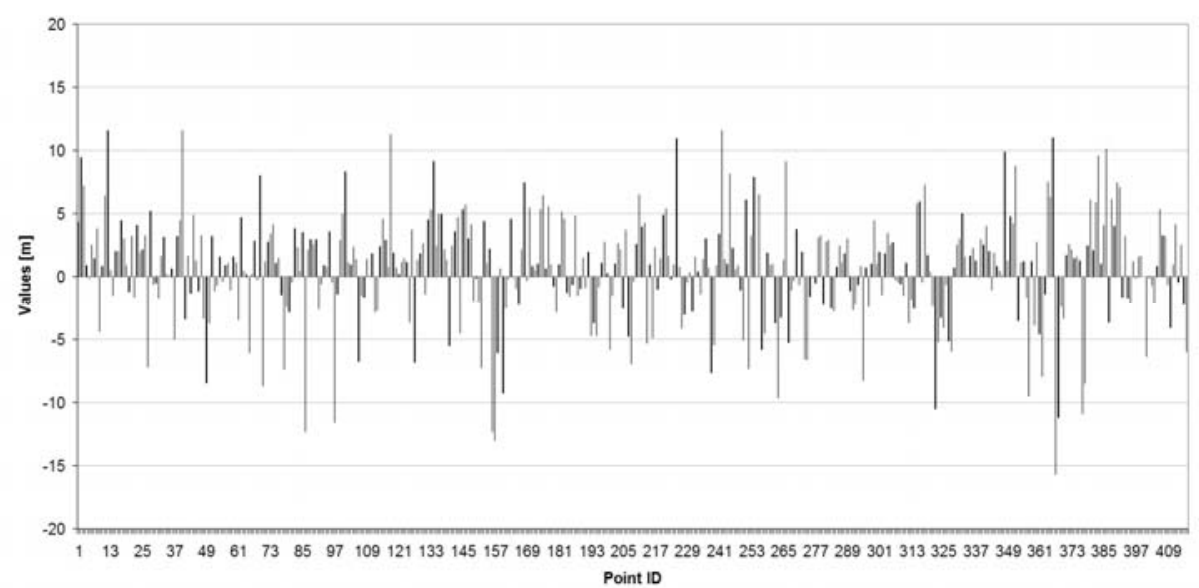

FIGURE 3. Relative elevation differences (in meters) between TOPO DEM 20 and SRTM DEM 90

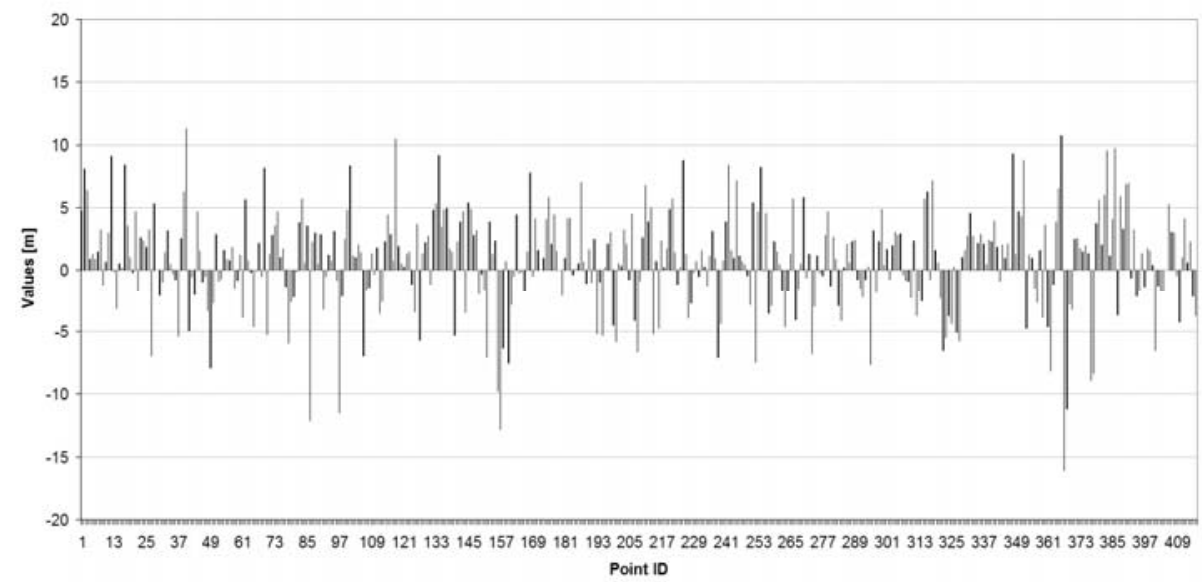

FIGURE 4. Relative elevation differences (in meters) between TOPO DEM 20 and SRTM DEM 20 (resampled from SRTM DEM 90)

shows that in this case resampling of SRTM data gives values closer to mean value, more "smoother" which should limit the influence of anomalous values i.e. from radar echo reflected from tree tops.

\section{Slopes}

Slope values generated from TOPO DEM 20 are between $0-36 \%$. For SRTM DEM slope values are in range of 0
$-14 \%$ (SRTM90) and 0-24\% (SRTM20). Therefore maximum values are higher in TOPO DEM. Furthermore in comparison with TOPO DEM slope information is more generalized and overall share of mean values is greater because of model resolution (SRTM90) but suprisingly SRTM20 is much like TOPO DEM (but it had no positive effect on further computations). Relative slope differences between TOPO DEM 20/SRTM DEM 


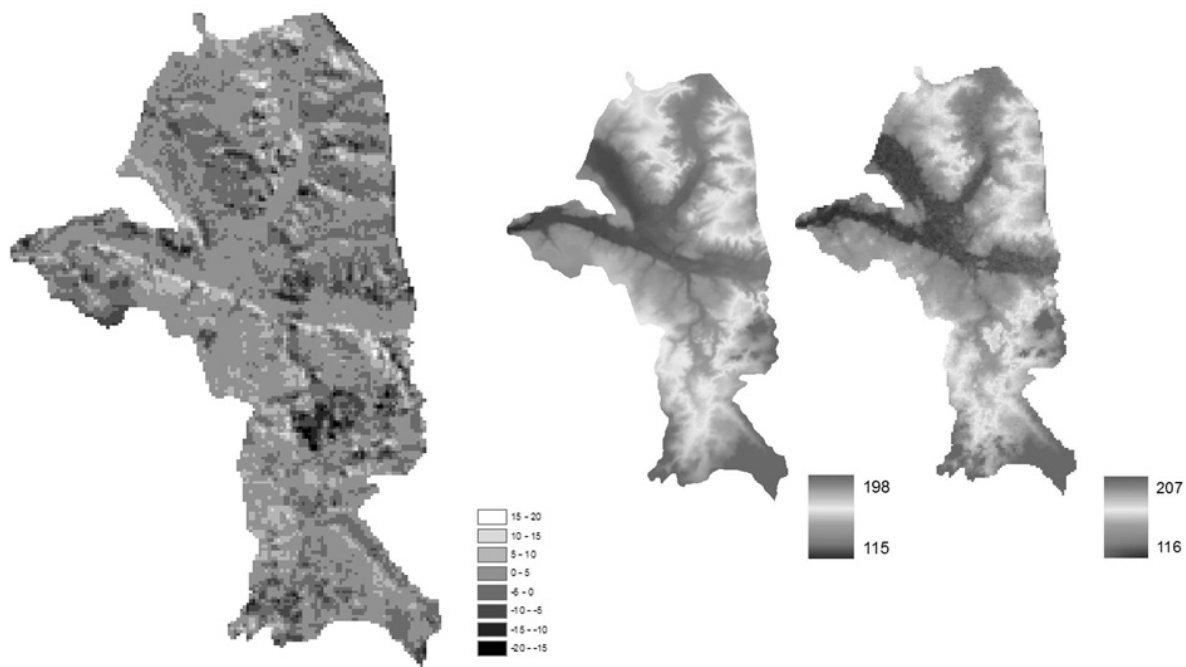

FIGURE 5. Relative elevation differences in meters (on the left) and absolute heights in meters a.s.l. (on the right - TOPO DEM 20 and SRTM DEM 90 respectively)

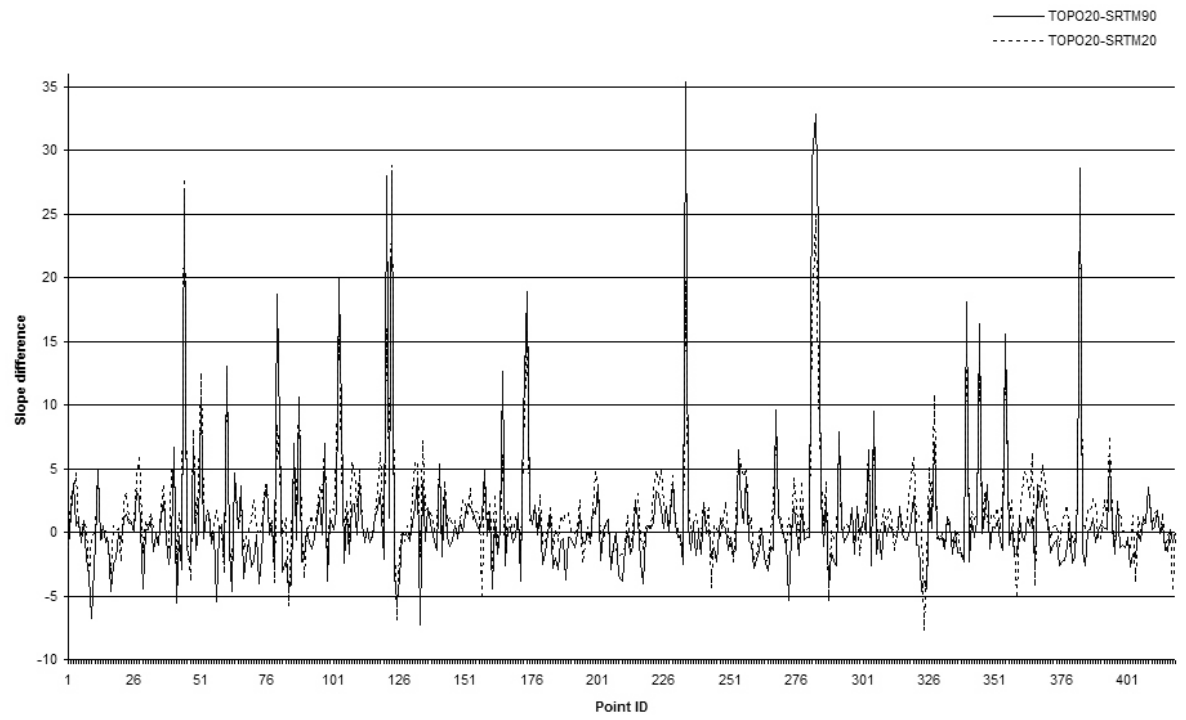

FIGURE 6. Relative slope differences; TOPO DEM 20/SRTM DEM 90 and TOPO DEM 20/SRTM DEM 20

90 and TOPO DEM 20/SRTM DEM 20 shows Figure 6.

Mean difference value between TOPO20 and SRTM90 is 0.9 ; between TOPO20 and SRTM20 is 1.6. Standard deviation is 5.2 and 4.1 respectively.

\section{Generated stream network}

Using ArcGIS' hydrological module, stream network was generated. As is seen on Figure 7 both DEMs have questionable areas. For TOPO DEM 20 


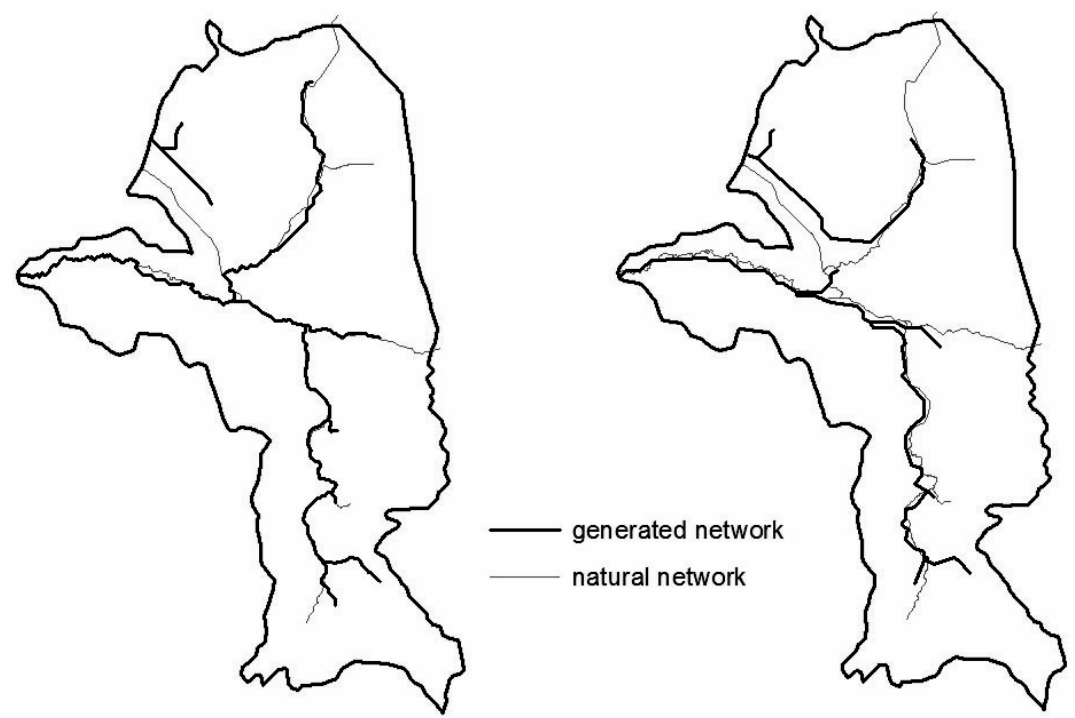

FIGURE 7. Generated stream network (bold lines inside) compared to existing one (thin, lighter lines) - TOPO DEM 20 on the left, SRTM DEM 90 on the right

one of the streams does not connect to the rest of the network in NW part of the catchment. It's worth noting that actually existing stream is of artificial origin. SRTM DEM 90 is problematic at nearly the same spot. The difference is that Niedźwiedzica River connects with artificial stream ignoring remaining network (however generated stream network seems to be more complete than analogous one for TOPO DEM).

Taking TOPO DEM as a reference more corresponding with actual state is network derived from SRTM 20. This is due to larger cells in SRTM 90 (Tab.
2). Almost $79 \%$ of SRTM DEM 20 cells identified as streams lies in 20 meter range (reference grid resolution) from its counterpart from TOPO 20 dataset. Percentages are calculated in reference to TOPO 20 total cell number because TOPO 20 cells were in fact assigned a corresponding SRTM cell.

\section{Generated subcatchments}

Figure 8 shows generated subcatchments. There are some errors which cause that generated sub-catchments do not fill whole analysis area (shaded parts denote erroneous parts). For TOPO DEM

TABLE 2. Analysis of stream networks concurrence - cells at distance of $20 \mathrm{~m}$ in any direction from given TOPO 20 cell

\begin{tabular}{|l|c|c|c|}
\hline Dataset & Number of cells & $\begin{array}{c}\text { Number of cells at distance of } \\
20 \mathrm{~m} \text { in any direction from given } \\
\text { TOPO20 cell }\end{array}$ & $\begin{array}{c}\text { Percentage of TOPO 20 cells } \\
\text { having counterpart at distance of } \\
\text { 20 m in any direction [\%] }\end{array}$ \\
\hline SRTM 90 & 368 & 176 & 12.90 \\
\hline SRTM 20 & 1219 & 1072 & 78.59 \\
\hline TOPO 20 & 1364 & & \\
\hline
\end{tabular}



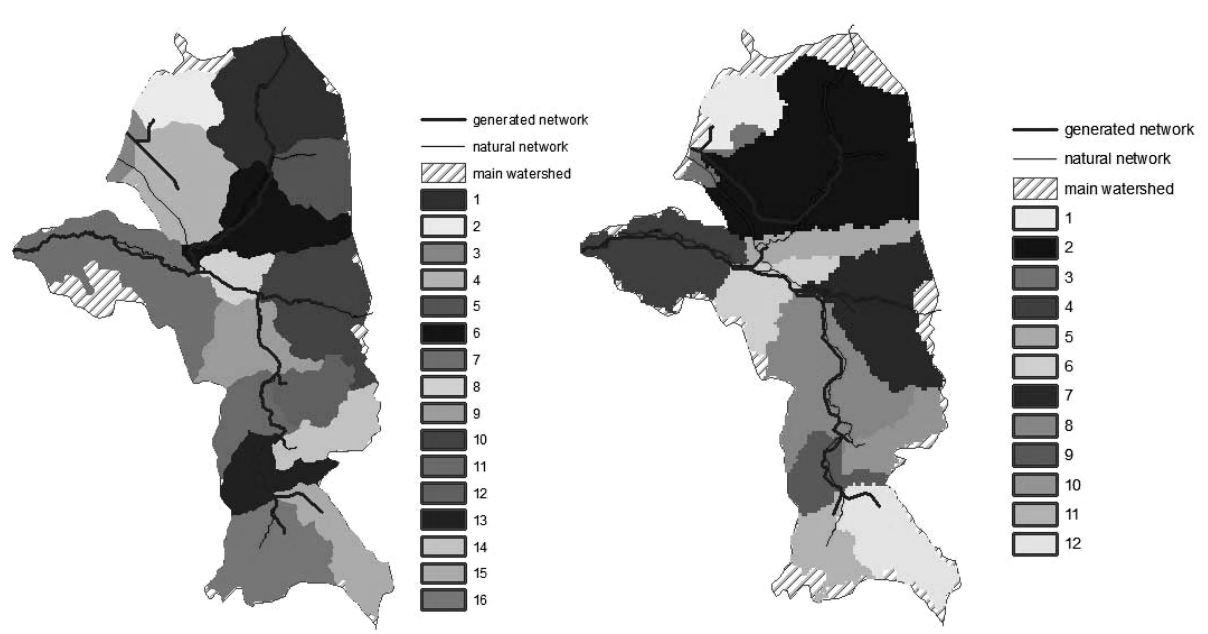

FIGURE 8. Generated subcatchments for analyzed part of basin - TOPO DEM 20 on the left, SRTM DEM 90 on the right. Numbers describe consecutive subcatchments; shaded parts point out areas with no subcatchment assigned

20 big gap appears in subcatchment closed in main catchment's terminating profile while the same place seems to be interpreted correctly in SRTM DEM. Small gaps are visible also in northern and southern parts of analyzed area both for topographic and radar models. TOPO DEM has fewer gaps in coverage of generated subcatchments.

Algorithmcalculated 16 subcatchments based upon TOPO DEM 20 and 12 based upon SRTM DEM 90 and 20. More corresponding with actual state seem to be subcatchments generated from TOPO DEM 20. Subcatchments generated from SRTM DEMs are similar with exception for northern part of analyzed area.

\section{Enhancing results}

So far all analyses were performed on raw data, not corrected towards hydrological needs i.e. DEMs were not "burnt" with stream network. They proved their usefulness however. But what if we actually applied mentioned corrections?
Figure 9 presents stream networks generated from reconditioned DEMs (i.e. "burnt" DEMs). Resultant networks are quite compatible with existing one. Looking at the picture, there are: existing stream network (Fig. 9-1), network generated from TOPO DEM 20 (Fig. 9-2), network generated from SRTM DEM 90 (Fig. 9-3) as well as network generated from SRTM DEM 20 (resampled from SRTM DEM 90 - Fig. 9-4).

Figure 10 shows subcatchments generated from the same datasets. They tend to have gaps in similar areas compared to results obtained from raw data. Number of sub-basins decreased in all three cases. Significant change is noticed for subcatchment closing in terminating profile of main catchment especially for SRTM DEM 90 where there are no gaps and empty areas observed before. For SRTM DEM 20 empty areas exist but are significantly smaller. 

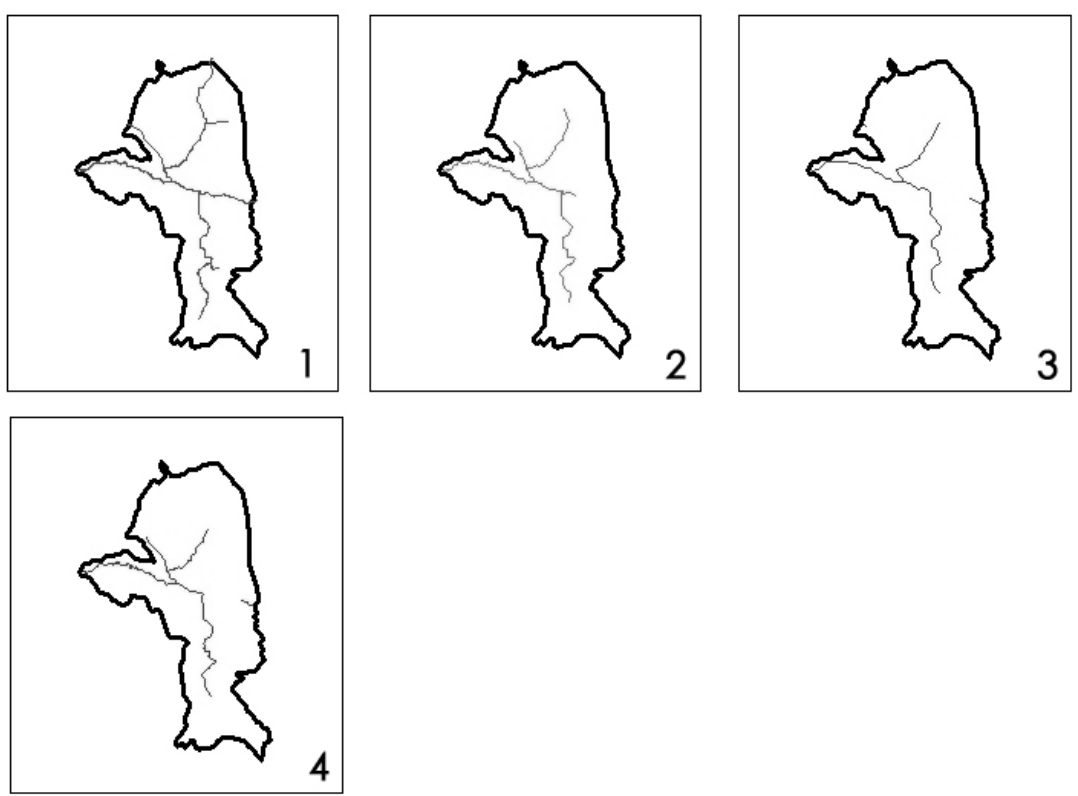

FIGURE 9. Stream networks generated from reconditioned DEMs; existing stream network (1), network generated from TOPO DEM 20 (2), network generated from SRTM DEM 90 (3), network generated from SRTM DEM 20 (4)
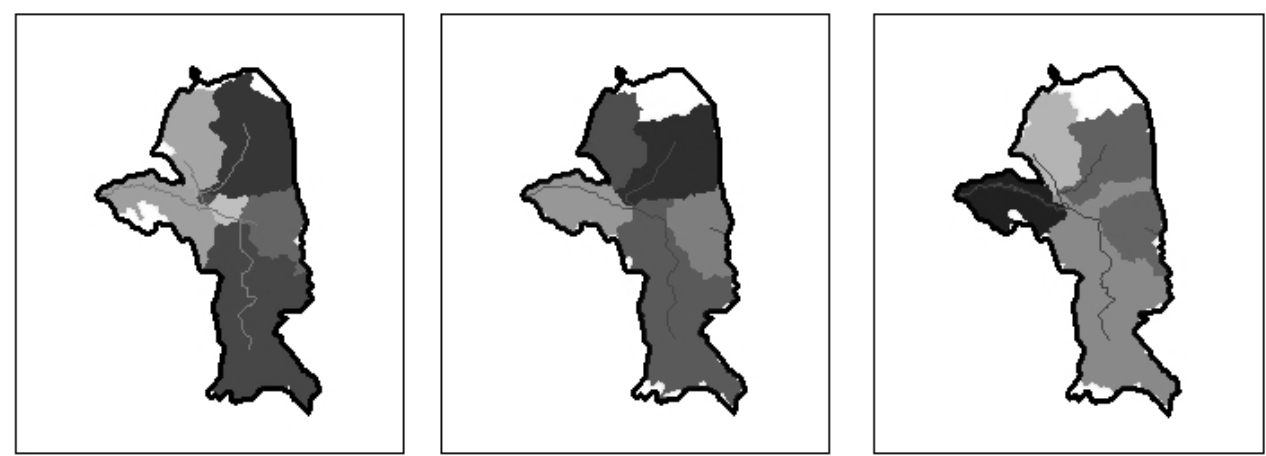

FIGURE 10. Subcatchments generated from reconditioned DEMs; TOPO DEM 20, SRTM DEM 90, SRTM DEM 20 respectively. White areas denote areas for which appropriate subcatchment was not computed

\section{CONCLUSIONS}

Results of raw data analysis show that all major ground features of study area are preserved and rendered correctly in SRTM DEM. Range of height values is slightly greater in SRTM DEM compared to TOPO DEM; $90 \%$ of height differences enclose in SRTM DEM absolute error range for Poland's territory. Despite some imperfections, stream network and subcatchments generated from raw SRTM DEM 90 can be considered sufficient depending on expected accuracy of application. 
Jarvis (Jarvis et al. 2004) proved SRTM DEM to be more accurate than analogous TOPO DEM generated from topographic data in scale of 1:50 000. At the same time his research shows SRTM DEM to be less accurate than $25 \mathrm{~m}$ TOPO DEM generated from topographic data in scale of 1:10 000 for his analysis area. Karwel (Karwel, Ewiak 2006) concludes that SRTM accuracy for flat areas in Poland is around $1 \mathrm{~m}$.

Work described in this paper regarding comparison of SRTM DEM (generated with radar interferometry) and TOPO DEM (interpolated from 1:25 000 topographic map's elevation isohypses) seem to confirm Jarvis' observations and concur with Karwel's. Certainly SRTM DEM 90 or SRTM DEM 20 are less accurate than TOPO DEM 20 because of resolution and resampling ${ }^{1}$ issues. However, under condition of data insufficiency SRTM DEM 90 can be used to supplement lacking $20 \%$ of catchment area with necessary characteristics.

Situation improves to some extent (in hydrological sense) after applying corrections i.e. "burning" stream network onto respective DEMs. There is no improvement in heights or slopes (as they are not subject to this corrections) - characteristic that is affected is hydrologic accuracy. Generated streams start to more fully resemble existing network and generated subcatchments improve in several areas.

In this particular case there should not be any major problems when using SRTM DEM data as supplementary source. This is due to fact that this region (deficient part of basin) has no major river network

\footnotetext{
${ }^{1}$ Where applicable.
}

and should not influence rest of the area in a significant way. Therefore minor imperfections in SRTM DEM derived characteristics should prove irrelevant.

\section{ACKNOWLEDGEMENTS}

The research described in this paper was prepared with help of research grant No 504-05260016.

\section{REFERENCES}

CHORMAŃSKI J., BATELAAN O., DE SMEDT F., VAN DE VOORDE T., CANTERS F. 2007: Application of a distributed GIS model for studying surface runoff processes in an urban wetland. In Okruszko T., Maltby E., Szatyłowicz, J., Mirosław-Świątek D., Kotowski W., Taylor \& Francis/Balkema [Eds.] Wetlands: Monitoring, Modelling, Management., The Netherlands: 189$-196$.

De SMEDT F., LIU Y.B., GEBREMESKEL S. 2000: Hydrologic modeling on a catchment scale using GIS and remote sensed land use information. In C.A. Brebbia [Ed.] Risk Analysis II. WTI press, Southampton, Boston, pp. 295-304.

HELLWEGER F. 1997: AGREE - DEM Surface Reconditioning System. http:// www.ce.utexas. edu/prof/maidment/ GISHYDRO/ferdi/research/agree/agree. $h$ tml.AGREE

HUTCHINSON M.F. 1996: A locally adaptive approach to the interpolation of digital elevation model. Third International Conference/Workshop on Integrating GIS and Environmental Modeling, Santa Fe, NM, January 2126, 1996. Santa Barbara, CA: National Center for Geographic Information and Analysis http://www.ncgia.ucsb. edu/ 
conf/SANTA FE CD-ROM/sf papers/ hutchinson michael dem/local.html

JARVIS A., RÜBIANO A. Comparison of SRTM derived DEM vs. topographic map derived DEM in the region of Dapa. International Center for Tropical Agriculture CIAT.

JARVIS A., RUBIANO J., NELSON A., FARROW A., MULLIGAN M. 2004: Practical use of SRTM data in the tropics - Comparisons with digital elevation models generated from cartographic data. International Center for Tropical Agriculture CIAT.

KARWEL K.A., EWIAK I. 2006: Estimation of the accuracy of the srtm terrain model in Poland. Archiwum Fotogrametrii, Kartografii i Teledetekcji, Vol. 16

KRAUS K., BRIESE C., ATTWENGER M., PFEIFER N. 2004: Quality measures for digital terrain models. Vienna University of Technology, Delft University of Technology.

LIU Y. 2004: Developement and application of GIS-based hydrological model for flood prediction and watershed management. $V U B-H y d r o l o g i e$ (46), Brussel.

LIU Y., GEBREMESKEL S., DE SMEDT F. 2002: Flood prediction with the WetSpa Model on catchment scale. Science Press, New York.

MULLER J.P., LI Z. 2004: Assessment of SRTM DEM data for landslide susceptibility mapping and for use in processing ERS and ENVISAT dIfSAR. Department of Geomatic Engineering, University College London, UK.

RODRIGUEZ E., MORRIS C.S., BELZ J.E., CHAPIN E.C., MARTIN J.M., DAFFER W., HENSLEY S. 2005: An Assessment of the SRTM Topographic Products. Jet Propulsion Laboratory JPL.
TARBOTON D.G., BRAS R.L., RODRIGUEZ-ITURBE I. 1991: On the Extraction of Channel Networks from Digital Elevation Data. Hydrological Processes. Vol. 5, pp. 81-100.

WANG Z., BATELAAN O., De SMEDT F. 1996: A distributed model for Water and Energy Transfer between Soil, Plants and Atmosphere. Phys. Chem. Earth, 21(3), 189-193.

Streszczenie: Numeryczny Model Wysokości $z$ misji SRTM (Shuttle Radar Topography Mission) jako alternatywne źródto wyznaczania charakterystyk hydrologicznych $w$ zlewni nizinnej na przykladzie zlewni Rogożynek. Ta publikacja opisuje możliwość uzupełniania danych numerycznego modelu wysokości wymaganych jako wejście w modelu WetSpa dla zlewni nizinnej o dane uzyskane z ogólnodostępnego modelu wysokości uzyskanego w misji SRTM (Shuttle Radar Topography Mission) rozpoczętej przez NASA 11 lutego 2000 roku. Analizy przeprowadzono na przykładzie zlewni Rogożynek znajdującej się w górnym biegu rzeki Biebrzy. Autorzy porównali trzy NMT: topograficzny - TOPO DEM 20 (o rozdzielczości $20 \mathrm{~m}$ ), radarowy - SRTM DEM 90 (rozdz. $90 \mathrm{~m}$ ) oraz radarowy o sztucznie zwiększonej rozdzielczości - SRTM DEM 20 (rozdz. $20 \mathrm{~m}$ ). Porównywano i analizowano kilka charakterystyk, m.in.: względne różnice wysokości, spadki, wygenerowane z NMT sieci rzeczne oraz wygenerowane zlewnie cząstkowe.

\section{MS. received April 2009}

\section{Authors' address:}

Department of Hydraulic Engineering and Environmental Recultivation Warsaw University of Life Sciences - SGGW Nowoursynowska Str. 159, 02-776 Warszawa tel./fax (+48 22) $5935316 / 5935320$, e-mail: M.Wasilewski@levis.sggw.pl J.Chormanski@levis.sggw.pl 